\title{
Influence and Countermeasures of "Business Tax Changed to VAT" on the Financial Accounting in Colleges and Universities
}

\author{
Xianfeng Yan \\ Jiangsu University of Science and Technology, Jiangsu, Zhenjiang 212003, China. \\ yan212003@foxmail.com
}

Keywords: tax reform of business tax changed to VAT, college and university, financial accounting, countermeasure and suggestion.

\begin{abstract}
Business Tax Changed to VAT" has great influence on the determination of taxpayer identity and the overall effect on paying taxes. Colleges and universities should do a good job of the policy interpretation and publicity, and seek an effective way of financial management, so that the funds management tends to optimize in this reform. This paper analyzed the impact on financial accounting in colleges and universities created by the "Business Tax Changed to VAT", proposed several countermeasures and suggestions in process of reform.
\end{abstract}

\section{Introduction}

On July 31, 2012, according to the spirit of 212th executive meeting of the state council, [1] the ministry of finance and the state administration of taxation decided to issue a notice about Beijing at the Treasury and other eight provinces and municipalities to carry out the transportation industry and part of the modern service industry tax change paid VAT pilot notice, Clear the transportation industry and part of modern service industry taxchange scope of paid VAT pilot, pilot by Shanghai partial expanded to Beijing, tianjin, jiangsu, zhejiang and other provinces and cities, on August 1, 2013 pilot opened throughout the country. The expanded VAT reform around the main purpose is to avoid double taxation, cannot offset the disadvantages of cannot drawback, straighten out the economic relations of different industries. Camp to increase is to perfect the tax system, the significance of double taxation problems to a certain extent, reduce the corporate tax cost to enhance enterprise development ability; Promote transformation and upgrading of enterprises and the development of service industry, optimize the industrial structure; Promote the specialization of social division of labor and industrial integration three times; beneficial to optimize the investment, consumption and export structure, promote the coordinated development of national economy.

As the forefront of science and technology innovation, colleges and universities is an important part of developing, according to the national, provincial, municipal relevant business tax relief policies, higher education in colleges and universities to provide business, undertake business of longitudinal research projects and the international exchange business income gained by the belong to nonprofit revenue, shall be exempted from business tax. Colleges and universities mainly by the taxable services are[2] (1) research and development and technical services, mainly including technology development, technology transfer, technical consulting, technology services, referred to as the "four technical services";(2) the assets of foreign rent, loan business, and do not belong to the scope of duty-free non-academic education business, etc.;(3) cultural creative services, including design, retrieval, meetings, etc.;(4) verification consulting services, including the detect cost and so on. Above, by the taxable services within the scope of the pilot reform should change from the business tax paid VAT. Combining with the present situation of colleges and universities, the tax change after the camp to increase effect analysis. 


\section{Organization of the Text}

\subsection{Analysis of the effect of"Business Tax Changed to VAT"on the financial accounting in}

Colleges and Universities

\subsubsection{Colleges and universities taxpayer qualification}

Initially based on the general VAT taxpayers that measures for the administration of the relevant provisions, hand out of place in the average taxpayer cognizance of colleges and universities, therefore "camp to increase at the beginning of the pilot," colleges and universities generally apply for small-scale taxpayers. If, after the "battalion to add" university services implement a taxable sales more than 5 million Yuan, the service will be regarded as general VAT taxpayers. Different tax qualifications of general taxpayer and small-scale VAT taxpayer qualification differences, advantages and disadvantages.(See the table 1 below)

\begin{tabular}{|l|c|c|c|c|l|}
\hline No. & $\begin{array}{c}\text { Taxpayers } \\
\text { category }\end{array}$ & $\begin{array}{c}\text { Tax } \\
\text { rate }\end{array}$ & $\begin{array}{c}\text { Input tax } \\
\text { deductio }\end{array}$ & Tax & \multicolumn{1}{|c|}{ pros and cons } \\
\hline 1 & $\begin{array}{c}\text { General } \\
\text { taxpayers } \\
\text { (common } \\
\text { calculation) }\end{array}$ & $6 \%$ & Yes & {$[\mathrm{A} \div(1+6 \%) \times 6 \%]$-input tax } & $\begin{array}{l}\text { Universities are qualified to issue } \\
\text { general invoice and special VAT invoice. } \\
\text { Compared to past tax policy, the risk } \\
\text { could be reduced if input tax is greater } \\
\text { than A } \div(1+3 \%) \times 3 \% \text { otherwise the tax } \\
\text { would be increased. The procedures of } \\
\text { accounting and declaration are complex }\end{array}$ \\
\hline 2 & $\begin{array}{c}\text { General } \\
\text { taxpayers } \\
\text { (simple } \\
\text { calculation) }\end{array}$ & $3 \%$ & No & $\mathrm{A} \div(1+3 \%) \times 3 \%$ & $\begin{array}{l}\text { Universities are qualified to issue } \\
\text { general invoice and special VAT invoice. } \\
\text { Compared to past tax policy, the tax } \\
\text { would be decreased under VAT. The } \\
\text { procedures of accounting and } \\
\text { declaration are simple. }\end{array}$ \\
\hline 3 & $\begin{array}{c}\text { Small-scale } \\
\text { taxpayers }\end{array}$ & $3 \%$ & No & $\begin{array}{l}\text { Universities are qualified to issue } \\
\text { general invoice, and special VAT } \\
\text { invoices can only be issued at tax } \\
\text { bureau. The tax would be decreased } \\
\text { under VAT compared to past tax policy. } \\
\text { The procedures of accounting and } \\
\text { declaration are simple. }\end{array}$ \\
\hline
\end{tabular}

\begin{tabular}{|c|l|l|l|}
\hline $\begin{array}{l}\text { Taxpayers } \\
\text { category }\end{array}$ & Tax before the policy change & Tax after the policy change & $\begin{array}{l}\text { decreasing } \\
\text { amplitude }\end{array}$ \\
\hline $\begin{array}{c}\text { General } \\
\text { taxpayers } \\
\text { (common } \\
\text { calculation) }\end{array}$ & $5 \% \mathrm{~A} \times[1+(7 \%+3 \%+2 \%)]=5.6 \% \mathrm{~A}$ & {$[\mathrm{~A} \div(1+6 \%) \times 6 \%] \times[1+(7 \%+3 \%+2 \%)]=6.34 \%$} & $13.21 \%$ \\
\hline $\begin{array}{c}\text { General } \\
\text { taxpayers } \\
(\text { simple } \\
\text { calculation })\end{array}$ & $5 \% \mathrm{~A} \times[1+(7 \%+3 \%+2 \%)]=5.6 \% \mathrm{~A}$ & {$[\mathrm{~A} \div(1+3 \%) \times 3 \%] \times[1+(7 \%+3 \%+2 \%)]=3.26 \% \mathrm{~A}$} & $-41.79 \%$ \\
\hline $\begin{array}{c}\text { Small-scale } \\
\text { taxpayers }\end{array}$ & $5 \% \mathrm{~A} \times[1+(7 \%+3 \%+2 \%)]=5.6 \% \mathrm{~A}$ & {$[\mathrm{~A} \div(1+3 \%) \times 3 \%] \times[1+(7 \%+3 \%+2 \%)]=3.26 \% \mathrm{~A}$} & $-41.79 \%$ \\
\hline
\end{tabular}

\subsubsection{A decline in the overall tax rate change}

Colleges and universities as a small-scale taxpayers have adjusted to $5 \%$ tax rate to pay business tax according to $3 \%$ tax rate to pay value added tax, tax burden by about $40 \%$, become the biggest 
beneficiaries to add "camp" pilot, reduce tax have increased spending on scientific research, is helpful to arouse the enthusiasm of teachers research have to. To increase overall, "camp" involved in part of the modern service industry covers most of the tax-related business scope in university, no matter how taxpayer subject nature, small-scale taxpayers or average taxpayer, the overall tax burden is falling. According to the regulation of the VAT payable calculated, providing taxable services with the original sales tax price adjustment for now no tax price, the actual tax burden of colleges and universities are lower than those of nominal tax burden, and with colleges and universities to provide research and development and technical services, [3] technical consulting business income increasing, the extent of tax is bigger, tax relief is more advantageous to the development of service industry of the colleges and universities, to speed up the development of colleges and universities.

\subsubsection{Expanding the scope of the deduction, perfect the buckle chain}

"Camp to add" received before operating income taxable services shall not touch buckle, "camp" instead, taxable services provider issue special VAT invoices, accept can sum corresponding VAT input tax deduction, even small-scale taxpayers provide revenue is $3 \%$ of the value-added tax invoices, the receiving party can also offset the input tax. For average taxpayer, from the original input tax deduction of raw materials and equipment, enlarge now deduction to the transportation industry and part of the modern service industry issue special VAT invoices. It and of the impact of the change, is not just about the appearance of pilot industry unit tax increase and decrease, but the impact on the industry chain and the improvement of the economic structure also has a very far-reaching significance. That layers of deduction of VAT chain, avoids double taxation, accept service enterprises reduce tax burden, reduce the enterprise cost, virtually promote university-enterprise cooperation.

\subsection{Camp to increase financial accounting countermeasures under the background of colleges and universities}

\subsubsection{Strengthen tax plan as a whole, and improving the capacity of tax-related business}

Camp to increase after the new recognition of the small-scale taxpayers tax rate reduces the colleges and universities, as a general taxpayer should dig clients on tax burden, because of VAT tax involved in circulation field, taxpayer can use circulation taxes on way, reduce the number of new taxes. Because the VAT input tax deduction regulation, colleges and universities can be gained by increasing circulation input VAT invoices, the deductible VAT, reduce taxable cost, increasing the service efficiency of funds. But between the content of university's scientific research mainly for labor, poor travelling expenses, the cost of raw materials, consulting fees, test processing, layout, and printing, etc., including labor, consulting fees, travel proportion bigger, rarely can obtain special invoices for value-added tax, which can offset the input tax of limited, camp to increase time may cause the tax burden is not rose, so be reasonable tax planning, take the initiative to deal with because of the impact of tax changes. Therefore, colleges and universities must strengthen accounting personnel training and continuing education, enhance the level of tax knowledge skills and professional ethics accomplishment, regularly invited tax department relevant personnel makes a detailed interpretation difficult tax issues, strengthen the tax-related business communication of other universities, promote tax business ability, to better meet the impact of the "camp" to the colleges and universities.

\subsubsection{Seize the opportunity for reform, improve the service efficiency of funds}

Camp has a strong orientation, instead it is using tax levers to reduce tax burden, promote industrial upgrading and technological progress, to the industry can be more lasting development of colleges and universities to develop innovative to provide energy and motivation. In front of the fund under the circumstances of less input tax deductible, financial personnel in colleges and universities can use policy as simple a small-scale taxpayers or average taxpayer. For general tax of colleges and universities as average taxpayer, as much as possible to obtain special invoices for value-added tax, travel is a tax deduction, reduce the tax burden, increasing the service efficiency of funds. 


\subsubsection{Improve college accounting treatment process, analyze the tax increase and decrease.}

Change under the background of increasing, the camp can be classified according to the concrete, as much as possible of different categories of taxes, calculated the respectively different business to evade tax risk, reduce taxes, to get more tax support, with enough with good tax policy, avoid tax inequities. According to current situation of university financial careful analysis, analysis can be used in the existing income tax deduction project in colleges and universities the proportion of total expenditure, determine whether these can be used to offset the input tax of VAT invoices obtained in a timely manner. If the price of the same situation, should choose to issue special VAT invoices of the unit.

\subsubsection{To strengthen the internal control of colleges and universities, strengthen the duty-free project management}

"Camp to increase", colleges and universities to reorganize financial internal control, strengthen the VAT tax returns, authentication, deduction of the supervision and management, especially for paper receiving, issue, use of management, to do follow the national tax administration system, formulate and implement response measures to add "camp", way, make up for the loopholes. Strengthen the ability of accounting, regularly or irregularly for financial control and financial audit, timely find some weak links that exist in the tax-related business, increasing tax related foundation work, reduce the tax risk, reduce the tax burden of colleges and universities. According to the provisions of the state administration of taxation on VAT deduction, the general taxpayers shall not use the special invoices for value-added tax in the tax and non-tax project for income tax deduction, the cocentration payment of the project in colleges and universities, tax-free transverse longitudinal research projects, and escrow payment shall not use the special invoices for value-added tax for income tax deduction, value-added tax invoices can only be deductible in the taxable items, if error deduction, as free end of VAT input tax to be turned out of the project, if not strictly distinguish between, will produce very big tax risk.

\subsubsection{To strengthen the management of invoices, reduce tax-related risks}

In the collection and management system, falsely making out VAT invoices and other than the business tax is more strict and perfect, make the fords the tax risk further. To increase in the "camp", after the special VAT invoice and commercial invoice are applicable in the college, improved the invoice management requirements in colleges and universities, in the process of invoice management, must be in strict accordance with the relevant provisions of the implementation of make out an invoice issued, use, and shall turn over, make the VAT invoice, operation process and system regulations issued VAT process of colleges and universities, to prevent the business people falsely making out VAT invoice to bring the legal risk and financial risk in colleges and universities, colleges and universities should strengthen the internal supervision and internal audit, improve the degree of attention to the invoice management, prevent the economic loss.

\section{Summary}

With the advancement of camp to increase, the requirement of the tax administration in colleges and universities is becoming more and more high, how to reduce the university taxes as far as possible, to ensure smooth change of excessive, is each financial personnel in colleges and universities need to think about problems, we should grasp the opportunity to camp to increase to increase the challenge confronting camp, through the theory research and practice to explore unceasingly, dig through the camp to increase, the provisions of the tax support for the development of colleges and universities to provide comprehensive.

\section{References:}

[1]Study Material For The 2014 National CTA Eaxm - Tax Law（II） [M].Bei Jing, China Tax Publishing House, 2014,p186-188

[2]Ministry of Finance Notice Of The Ttate Administration Of Taxation about the change from 
business tax to VAT in transportation industry and part of modern service industry.[S] Fanance and Taxation [2013]37

[3] Liu Caipin The influence and discussion about the change from business tax to VAT in colleges and universities. [J].Friends of Accounting,2014,(3) p.111-113 